Grażyna Golik-Górecka, Paula Syty

\title{
Wskaźniki marketingowe dla decydentów determinujące wzrost roli marketingu
}

\author{
Zysk nie jest wyjaśnieniem, przyczyną czy racjonalną przesłanką \\ zachowań i decyzji biznesowych, lecz raczej testem ich zasadności. \\ P. Drucker \\ Wczorajsze dane na temat oczekiwań i doświadczeń klientów to \\ jedynie historia. Dzisiejsze wiadomości na temat oczekiwań \\ i doświadczeń klientów to jutrzejsze zyski. \\ J. Robinson
}

\section{Wstęp}

Celem artykułu jest przybliżenie problemów związanych ze wskaźnikami dla decydentów, które jednocześnie wpływają na wzrost roli i skuteczności marketingu. Sposób doboru wskaźników może być zaczerpnięty z tablicy wskaźników marketingowych, pozyskiwanych dzięki badaniom marketingowym oraz czynnikom wewnętrznym i zewnętrznym otoczenia przedsiębiorstwa. Czynniki mogą pochodzić także z proponowanych dwóch kart wyników klienta i interesariusza przy wykorzystaniu dashboardu i jego czterech ścieżek mierników konsumenckich, jednostkowych, finansowych i marki.

Powyższe cytaty wielkich autorytetów marketingu, precyzyjnie wskazują sposób osiągania celów strategicznych przedsiębiorstw. Firmy, które chcą zapewnić sobie rosnące zyski, realizację strategii działania, zwiększenie udziału w rynku oraz obszaru działalności, muszą prowadzić i organizować swoją działalność spełniając kryteria racjonalnego gospodarowania, efektywności ekonomicznej, skuteczności działań.

Przez racjonalność rozumie się wybieranie takiej struktury i sposobu działania, który jest najbardziej korzystny w procesie gospodarowania - należy pojmować ją jako możliwość uzyskiwania większych efektów przy danej wielkości 
zasobów lub tego samego poziomu efektów przy użyciu mniejszej ilości zasobów oraz ostatecznie skuteczność działania jako sprawne i szybkie osiąganie wyznaczonych celów.

Efektywnością ekonomiczną nazywać będziemy stosunek efektów do nakładów na działalność przedsiębiorstwa. W literaturze marketingowej częściej spotykamy się z pojęciami efektywności i skuteczności działań marketingowych, które przekładają się na te pojęcia w ujęciu ekonomicznym.

Przedsiębiorstwo spełni powyższe kryteria, a zatem osiągnie swoje cele, jeżeli sposób ich realizacji będzie poprawny. Oczywiście nie da się precyzyjnie określić, czy planowane działania przyniosą oczekiwane efekty lub czy istnieje inna, łatwiejsza i skuteczniejsza ścieżka postępowania. Trudności te występują z powodu ciągłych i trudno przewidywalnych zmian w otoczeniu organizacji. W celu kontroli poprawności działań przedsiębiorstwa wykorzystują wyniki badań marketingowych.

Na realizację tego procesu składają się cztery etapy:

- określenie problemu i celu - należy jasno sprecyzować, jakiej informacji poszukujemy;

- opracowanie planu badania, działań, które są niezbędne do przeprowadzenia badania, np. zebranie informacji o liczbie i strukturze klientów;

- przeprowadzenie badania;

- interpretacja wyników i wdrożenie rozwiązań stymulowanych pozyskanymi informacjami.

\section{Poziomy wykorzystania informacji, analiz i różnych ujęć wskaźników marketingowych}

Wraz ze zmianami zachodzącymi w organizacjach, łatwo można zauważyć znaczący wpływ roli marketingu na ich rentowność i zyski. Obecnie działające przedsiębiorstwa wykorzystują wnioski płynące z marketingu we wszystkich obszarach swojej struktury. Można wyodrębnić trzy podstawowe poziomy, zgodnie z którymi przedsiębiorstwa dzielą się informacjami z badań marketingowych. Poziomy te obejmują podstawowe jednostki organizacji, strategiczne jednostki biznesu oraz zarząd. Zauważamy więc hierarchię strategii tam, gdzie jak stwierdza W. Kąkol w rzeczywistości istnieje hierarchia strategii i tak na poziomie firmy czy korporacji realizuje się strategię rozwoju, poszczególne oddziały czy podmioty realizują wybrane strategie konkurencji, których z kolei szczegółowe cele są przypisywane strategiom funkcjonalnym - sprzedaży, promocji, finansów itd. 
Ponieważ rośnie znaczenie marketingu dla odniesienia sukcesu firmy, warto wiedzieć, które aktywa niematerialne przedsiębiorstwa pochłaniają największe koszty marketingowe i generują największą wartość. Dla zbadania kluczowych elementów generujących przewagę konkurencyjną, firmy stosują różne wskaźniki. Pozwalają one zwiększyć zyski lub zmniejszyć koszty ich kreowania, np. reklamy w telewizji, jeżeli jasno można stwierdzić, że jest znacznie mniej efektywna niż reklama w Internecie poprzez social-media.

Determinanty przedstawiania wskaźników marketingowych dla decydentów są konkretnymi pobudkami, dla jakich przedsiębiorstwo szacuje wskaźniki marketingowe i finansowe; poza/oprócz pobudzaniem efektywności zarządzania, skuteczności i racjonalizacji działania celem jest oczywiście budowanie trwałej przewagi konkurencyjnej, dzięki reakcji przedsiębiorstwa na wnioski wypływające ze wskaźników marketingowych.

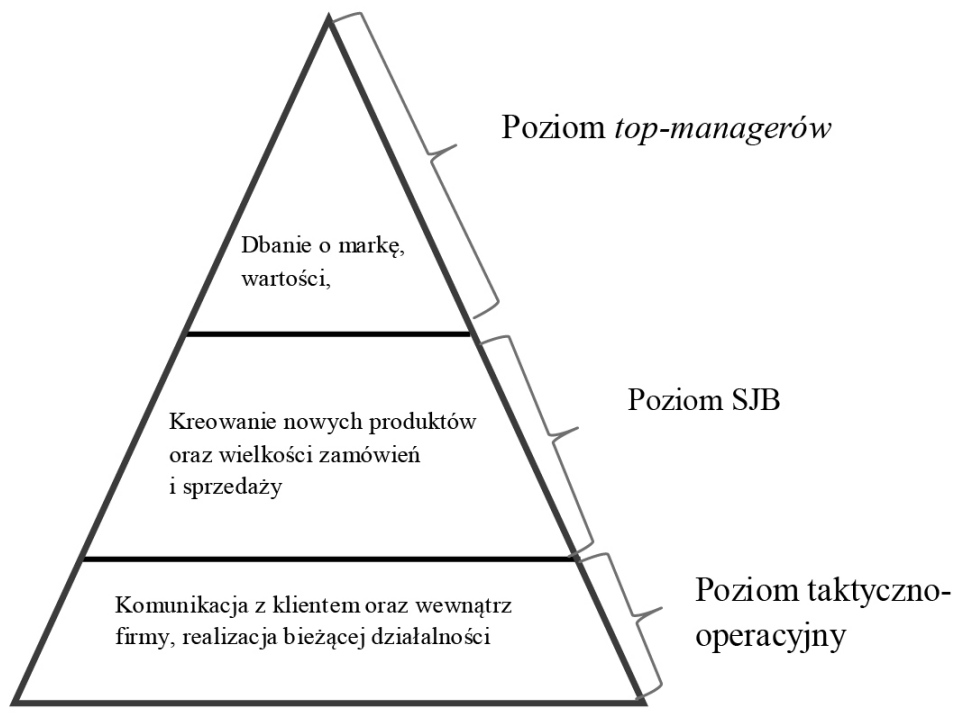

Rysunek 1. Trzy podstawowe poziomy wykorzystujące informacje i wyniki badań marketingowych

Źródło: opracowanie własne.

Skuteczne stosowanie działań marketingowych realizujących strategię firmy zapewnia wyznaczanie kierunku rozwoju firmy, realizację jej wizji i osiąganie celów ${ }^{1}$. Chęć osiągnięcia celów przedsiębiorstwa prowadzi do ustalenia wyboru rynku działalności przedsiębiorstwa, grupy docelowej i struktury produktów

${ }^{1}$ G. Golik-Górecka, Perspektywa marketingowo-finansowa a narzędzia decyzyjne zarządu przedsiębiorstw, „Handel Wewnętrzny” 2011, nr 5. 
oferowanych na tym obszarze. Dobre praktyki marketingowe tworzą wartość dla inwestorów, środowiska i klientów. Właściciele przedsiębiorstw nie tylko troszczą się o zyski, ale także o przetrwanie ich firmy w najdłuższej możliwej perspektywie czasowej, a więc wyniki badań marketingowych i wskaźników są podstawą wnioskowania o wartości przedsiębiorstwa (często używaną metodą jest DCF) i dają stymulację do poprawy działań mniej zyskownych lub zastosowania ścieżki osiągania celów strategicznych. Dla pozyskania informacji o zasobie danych, które są potrzebne do osiągania celów, zastosować można wskaźniki związane ze sprzedażą i dystrybucją produktów, przedstawiające wielkość sprzedaży, kanibalizacji produktowej. Również wskaźniki komunikacji marketingowej, tj. wielkości zamówień, kampanii reklamowych, ale także wskaźniki oceny strategicznej, najważniejsze z punktu widzenia klienta i marki: udziału w rynku, wzrostu sprzedaży satysfakcji klientów, ich lojalności i utraty, wartość marki (DCF) oraz wartości klienta (CLV) pozwalają na zobrazowanie skuteczności osiągania celów przedsiębiorstwa.

Wszystkie powyższe determinanty odnosiły się do czynników zewnętrznych przedsiębiorstwa. Istnieją jednak czynniki wewnętrzne, opisujące rozwój zasobów ludzkich w organizacjach, np. zatrudnienie pracowników o specjalnych kwalifikacjach, potrzeby inwestycji informatycznych - baz danych, dostrzeżenie klienta wewnętrznego, wymiana informacji pomiędzy działami itp. Dla określenia determinantów wewnętrznego rozwoju firmy można zastosować wskaźniki typu CLV: pozyskania, utrzymania i zysku z klienta, ROI.

Przedsiębiorstwa muszą zmienić sposób myślenia o powiązaniach w nich występujących i generować z nich jak największe zyski. Powinny dostrzec:

- zależność pomiędzy poprawną realizacją działań marketingowych a wzrostem wartości przedsiębiorstwa, konieczność sterowania marką firmy, zwiększanie jej wartości;

- trudność w utrzymywaniu się na tym samym stopniu rozwoju marketingowego co konkurencja.

W przeciwnym razie, nawet najbardziej innowacyjne działania przedsiębiorstwa nie przełożą się na długotrwały zysk.

Zanim firma przystąpi do selekcji wskaźników powinna zebrać jak największą bazę danych o klientach, ponieważ to dzięki nim może istnieć. Ważne jest, aby była prowadzona rzetelnie, dotyczyła możliwie najdłuższego okresu, zawierała informacje o obecnych i nowych klientach, strukturze ich zakupów i wartości klienta. Główną informacją jest zebranie informacji o potrzebach konsumentów, ich preferencjach względem produktów, asortymentu, cech użytkowych, obsługi klienta, cechach przedsiębiorstwa, które skłaniają nabywcę do wyboru produktów tej firmy. 


\section{Metoda doboru wskaźników marketingowych w celu kreacji strategii przedsiębiorstwa według tablicy wskaźników marketingowych}

W rzeczywistości nie istnieje jeden model zawierający w sobie wszystkie wskaźniki, których użycie gwarantuje osiągnięcie pełnego sukcesu, wskaźniki jedynie obrazują sytuację, ale warto dobierać je tak, aby ten obraz był klarowny i przejrzysty, inaczej dobranie kilku niepowiązanych ze sobą wskaźników nie da wymiernej informacji. Jak wcześniej zostało wspomniane, wskaźniki obrazują skuteczność działań marketingowych, których celem jest udowodnienie, że firma osiąga zakładane zwroty z inwestycji, oraz stwierdzenie, w jakim stopniu i w których konkretnie etapach realizuje strategię marketingową. Jednym z podejść decydowania o dalszym działaniu jest selekcja informacji płynącej z tablicy wskaźników marketingowych, jaką proponują autorzy artykułu Zarząd bliżej klientów ${ }^{2}$. Jednak w teorii i praktyce podjęto również inne próby zestawień wskaźników marketingowych, np. ujęcie marketingowej zbilansowanej karty wyników oraz wskaźniki według $\mathrm{Ph}$. Kotlera wykorzystywane w kokpicie sterowniczym marketingu, czyli dashboard marketing.

Pierwotnym wzorcem wskaźników marketingowych, który przedstawiony został w HBR Polska jest tablica wskaźników marketingowych. Przedsiębiorstwa powinny stosować tę tablicę wskaźników marketingowych ${ }^{3}$, ponieważ ma ona służyć podejmowaniu efektywnych działań marketingowych, rozwiązaniu trudności w procesach marketingowych, monitorowaniu postępów i szybkiej eliminacji błędnych działań. Tablica powinna być przedstawiona decydentom budującym strukturę działalności przedsiębiorstwa oraz zarządom firm, aby mieli klarowne spojrzenie na wszystkie elementy wpływające na budowanie wartości ich firmy i ich oddziaływanie na osiąganie strategicznych celów przedsiębiorstwa.

Pierwszym elementem tabeli są czynniki uwydatniające wzrost firmy.

Czynniki dotyczące wzrostu firmy to takie czynniki, które mają bezpośredni wpływ na wynik finansowy firmy, określany na podstawie prognoz. Konstrukcja doboru wskaźników powinna odzwierciedlać taką strukturę, która da wymierny obraz jej wpływu na zyski spółki. Jasne jest, że przedsiębiorstwo komunikacyjne będzie zwracało uwagę na wskaźnik lojalności klientów oraz liczbę nowych klientów, ponieważ oferta ściśle wiąże się z przedłużaniem umów zaraz po ich wygaśnięciu lub zawieraniu nowych. Jeżeli stopień lojalności będzie niski łatwo

2 D.J. Court, J.A. Quelch, B. Crawford, G.J. McGovern, Zarząd bliżej klientów, „Harvard Business Review Polska" 2008, nr 12, s. 64.

Ibidem. 
można wywnioskować, że klienci pozostają nabywcami tylko na czas obowiązywania umowy, a więc należy podjąć działania, które utworzą taką strukturę obsługi, oferty i kosztów, jaka będzie atrakcyjna dla klienta i przekona go do pozostania nim dłużej. Ph. Kotler proponuje takie trzy grupy wskaźników opiniujących skuteczność strategii, jak:

- mierniki dotyczące sprzedaży: wzrost sprzedaży - i jego tempo, udział w rynku i tempo rozwoju przedsiębiorstwa, udział nowych produktów w sprzedaży i zysk na jednostce produktư;

- mierniki dotyczące skłonności klientów do zakupu to ${ }^{5}$ : świadomość marki, preferencja nabywców, intencja zakupu, stopa ponownych zakupów;

- mierniki dotyczące klientów to m.in. skargi klientów, satysfakcja klientów, stosunek osób polecających do odradzających, koszty pozyskania klienta, zysk przypadający na na nowego klienta straty wynikające $\mathrm{z}$ obsługi klienta, rotacja klientów, stopa zatrzymania, wartość życia klienta, kapitał klienta, rentowność klienta, zwrot z inwestycji niezbędnej do pozyskania klienta.

Czynniki ściśle związane ze sprzedażą, klientami i skłonnością do zakupów pozwalają na poprawną prognozę przyszłych zysków i zachowań nabywców, a co za tym idzie projektowanie nowych produktów dopasowanych do potrzeb nabywców i spełniających ich oczekiwania w najlepszy możliwy sposób. Interpretacja skarg i reklamacji oraz serwisu posprzedażowego pozwoli na wychwycenie „wąskich gardeł" organizacji, a następnie ich poprawę i zbudowanie poczucia wśród klientów, że przedsiębiorstwo dba o nich, nawet gdy popełniło jakiś błąd.

Poszukując wartości wskaźników dla firmy ATLAS Sp. z o.o. warto wykorzystać te, które obrazują cele strategiczne firmy (2011-2012).

Są to wskaźniki oceniające wykorzystanie działań marketingowych na poziomie strategicznym, najbardziej kluczowych dla menedżerów najwyższego szczebla. Będą one wymiernymi informacjami dla takich celów, jak:

- Ciągłe dążenie do powiększania wartości firmy ATLAS.

- Budowa pozycji lidera regionalnego w obrębie kluczowych kompetencji.

- Budowa przewagi rynkowej opartej na rozwijaniu rozwiązań systemowych.

- Doskonalenie metod zarządzania firmą.

- Dbanie o prestiż marki.

- Rozwijanie i wykorzystywanie potencjału zasobów ludzkich.

- Zapobieganie zanieczyszczeniom w środowisku naturalnym.

- Zapewnienie środków finansowych na bieżącą działalność i rozwój firmy

${ }^{4}$ Ph. Kotler, K.L. Keller, Marketing, Pearson Education, Poznań 2012, s. 692.

${ }^{5}$ Ibidem.

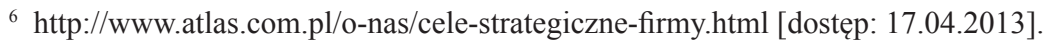


Zastosowanie wskaźników z tej grupy jest istotne, ponieważ opracowywanie strategii jest ciągłe i kluczowe dla przedsiębiorstwa, decyzje są obciążone dużym ryzykiem i niepewnością, gdyż informacje pozyskuje się z zewnątrz.

Długookresowym podstawowym celem przedsiębiorstwa jest maksymalizacja finansowych korzyści właścicieli, czyli maksymalizacja wartości danego podmiotu. Najczęściej jest to osiągane poprzez strategię rozwoju firmy. Duża firma nie realizuje jedynie strategii penetracji rynku, najczęściej staje się on bowiem zbyt mały, i zaczyna zdobywać nowe segmenty i nowe rynki geograficzne. Można stwierdzić, że obecna pozycja przedsiębiorstwa na rynku determinuje zarówno redefiniowanie, jak i wybór kolejnej strategii. Tak np. Atlas osiągając pozycję lidera na rynku chemii budowlanej zmienił swoją misję, wizję oraz redefiniował strategię zarówno całej korporacji, jak podmiotów wchodzących w jej skład. Strategicznym zagadnieniem marketingu jest więc określenie rynku docelowego oraz przewagi konkurencyjnej w osiągnięciu sprzedaży na tym właśnie rynku, ponieważ koncentruje się, jak wcześniej wspomniano, na klientach przyszłych i obecnych.

Dla przykładu, w firmie ATLAS sp. z o.o. wskaźnik liczby nowych klientów przełożył się na utworzenie 5500 punktów sprzedaży, firma zanotowała większą dostępność produktu ( $80 \%$ oferty). W odniesieniu do przychodu (ponad miliard złotych w 2009 r.) otworzenie nowych punktów dostępu oraz dopasowanie produktów do potrzeb klientów i innych wymogów spowodowało wzrost sprzedaży cementu z 20 do $25 \%$, a wyrobów gipsowych do $300 \%$. Tak dobre wyniki finansowe przedsiębiorstwo odnotowuje dzięki odzwierciedleniem w strukturze organizacji struktury jej klientów. Wartość klienta w jednym z programów firmy ATLAS wynosi 23-25 tys. w roku, a tworzenie takich programów podnosi udział w rynku nawet do $20 \%$.

Wiele firm, które chcą skutecznie realizować swoją strategię oraz mierzyć jej efektywność, wykorzystuje wskaźniki marketingowe. Do grona tych firm można dołączyć zarówno przedsiębiorstwa polskie, jak i zagraniczne. W pierwszej grupie znajdziemy takie firmy, jak: Wittchen, Bakaland SA, TRICOMED SA, Koło, obecnie należące do grupy Sanitec, PKN Orlen, Dr Irena Eris. Druga grupa to m.in.: American Airlines, South West, Microsoft, Coca-Cola, Ford, Wal Mart, Apple, Pepsi-Cola, Gilette, Hugo Boss, Delloite, KPMG, Ernst \& Young, PwC, Sephora, McDonald's i wiele innych. Mnogość podmiotów świadczy o istocie i wartości informacji, jakie wykazuje taka metoda analizy.

${ }^{7}$ G. Golik-Górecka, Zwiększenie efektywności marketingu podstawa sukcesów przedsiębiorstwa - ujęcie najlepszych praktyk - ATLAS Sp. z o.o., [w] A. Kaleta, K. Moszkowicz, Zarzadzanie strategiczne w praktyce i teorii, Wyd. Uniwersytetu Ekonomicznego we Wrocławiu, Wrocław 2012, s. 101. 
Drugim elementem tabeli są wskaźniki dotyczące produktów i pomysłów na nowe produkty.

Wskaźniki znajdujące się w tym obszarze mają za zadanie przedstawić strategiczne działania przedsiębiorstwa w celu utrzymania tempa wzrostu, które prognozuje się na podstawie informacji z pierwszej części. Powinny określać upodobania klientów względem:

- oferty produktowej i jej cech,

- innowacyjności produktów,

- użyteczności i funkcjonalności oferowanych już produktów.

Ta część tabeli powinna zawierać konkretne pomysły dotyczące nowych produktów z wyszczególnieniem przełożenia ich wartości na wzrost zysków, czas uzyskania tych zysków oraz warunki, jakie trzeba spełnić, żeby przychody osiągnęły szacowaną wielkość, a wszystko po to, żeby łatwiej zidentyfikować problemy w działaniach lub nierentowne produkty w przypadku niepowodzenia sprzedaży danego produktu.

Dla przykładu, firma ATLAS sp. z o.o. dysponuje ok. 210 produktami w 5 kategoriach, jej udział w rynku chemii budowalnej w 2007 roku wynosił 35-50\%, jest jedną z najlepiej rozpoznawanych marek w Polsce. Produkty, jakie oferuje firma, są wynikiem wewnętrznych badań technologicznych. Uwzględnianie potrzeb nabywców pozytywnie wpływa na wyniki finansowe przedsiębiorstwa. W 2011 roku firma sprzedała ok. 200 tys. ton wyrobów, posiadając udziały $60-70 \% \mathrm{w}$ rynku białoruskim, w Polsce jej udział w rynku wynosi ok. $70 \%{ }^{8}$.

W tym miejscu ponownie warto odnieść się do celów przedsiębiorstwa, aby precyzyjnie wybrać odpowiednie wskaźniki oceniające sprzedaż i dystrybucję towarów. Są to:

- Realizacja zaplanowanej sprzedaży na rynku krajowym.

- Realizacja zaplanowanej sprzedaży na rynkach zagranicznych.

- Rozwój asortymentu zgodnie z oczekiwaniami klienta.

- Projektowanie i doskonalenie wyrobów w aspekcie ekonomicznym, bezpieczeństwa i ochrony środowiska9 .

Trzecim elementem tabeli, najbardziej pożądanym ze względu na rozwój wewnętrzny, jest podkreślenie zasobów ludzkich i materialnych niezbędnych do kreacji i utrzymania wzrostu przedsiębiorstwa. Pracownikami powinny być osoby nie tylko kreatywne, ale potrafiące poruszać się w podstawowych obszarach przedsiębiorstwa, takich jak m.in. działy finansowe. Tabela powinna zawierać informacje o:

\footnotetext{
${ }^{8}$ Ibidem.

${ }^{9}$ http://www.atlas.com.pl/o-nas/cele-strategiczne-firmy.html [dostęp: 17.04.2013].
} 
- umiejętnościach, które są niezbędne do tworzenia wymienionych wcześniej produktów, utrzymywania tempa wzrostu;

- czynnikach marketingowych wpływająch na wzrost;

- analizie oceny strategii marketingowej danego przedsiębiorstwa;

- kompetencjach pracowników;

- sposobach na uzupełnienie braków w kompetencjach.

\section{Tablica przyrządów marketingowych - kokpit sterowniczy}

Zagadnienie zasygnalizowane w tytule mówi o wskaźnikach dla decydentów, a na rys. 1 wskazano także możliwości dla decydentów na każdym poziomie. Właściwie przedstawiają to $\mathrm{Ph}$. Kotler i K.L. Keller nawiązując do różnych rodzajów kontroli działań marketingowych. Dla zarządu i menedżerów średniego szczebla niezbędne są zarówno dane, jak i wskaźniki dotyczące planowania, monitoringu i kontrolowania analizy sprzedaży, analizy udziału w rynku, relacje sprzedaży do nakładów, analiza finansowa i karty wyników dla sprawdzenia wykonania planów. Ponadto dla zarządu istotna jest ocena skuteczności marketingu w celu sprawdzenia, czy firma podąża za najlepszymi szansami biznesowymi w odniesieniu do rynków, produktów i kanałów.

Dla kontrolera marketingowego ważne są rentowności dla produktu, regionu, klienta, segmentu, kanału handlowego i wielkości zamówienia. Z kolei dla menedżerów liniowych i sztabowych istotna jest poprawa efektywności inwestowanych nakładów, a także efektów wydatków marketingowych, czyli ważna jest efektywność działu sprzedaży, reklamy, promocji sprzedaży i dystrybucji ${ }^{10}$.

Zmiany w zarządzaniu oraz strategii przedsiębiorstwa przebiegają pod nadzorem menedżerów średniego szczebla. Ich zadania polegają na zaplanowaniu wdrożenia zmian, dokonaniu ich, monitorowaniu i kontrolowaniu efektów przy pełnej opiece merytorycznej dotyczącej wszystkich występujących problemów, których nie brakuje w procesach zmian w przedsiębiorstwie. Jednocześnie osoby zarządzające na średnim szczeblu przedsiębiorstwa są odpowiedzialne za informowanie i thumaczenie zmian występujących w przedsiębiorstwie, ich celowości i efektów, jakie firma chce osiągnąć. Chodzi również o naprawianie błędów występujących w bieżącej działalności, wynikłych w procesie zmian strategicznych, integrację pracowników i bieżące informowanie przełożonych o sytuacji w przedsiębiorstwie ${ }^{11}$.

${ }^{10} \mathrm{Ph}$. Kotler, K.L. Keller, op. cit., s. 691.

${ }^{11}$ G. Johnson, K. Scholes, R. Whittington, Podstawy strategii, PWE, Warszawa 2010. 
Aby dokonać optymalnego wyboru strategii i analizy oceny strategii marketingowej należy prowadzić zarówno monitoring pozycji zewnętrznej, jak i sytuacji wewnętrznej firmy, czyli istotna staje się przewaga konkurencyjna, która jest celem ruchomym wymagającym nieprzerwanych inwestycji. Wynika to z szybkich zmian zachodzących na rynkach i dlatego też, jak już wcześniej zauważono, należy wykorzystywać systemy informacji. Do pozyskiwania i analiz tych informacji służy tzw. dashboard - kokpit sterowniczy. Ten kokpit - dashboard, inaczej tablica przyrządów, ułatwia realizację decyzji dotyczących wprowadzania nowych produktów, pozwala na efektywniejsze wydatki i inwestycje marketingowe. Ten program wspomagający zarządzanie zasobami marketingowymi oferuje zestaw oparty na pobranych z Internetu aplikacjach, które automatyzują i integrują zarządzanie projektami, kampaniami, budżetem, narzędziami, markami i relacjami z klientem. Jednak to, że firma będzie miała systemowe narzędzie dashbordu nie daje szansy na sukces, istotne jest, czy dana firma wykorzystuje umiejętnie dashboard oraz informację i wyniki analiz ${ }^{12}$.

P. Lapoint zwraca uwagę na przydatność marketingowych tablic przyrządów, które zawierają dane niezbędne dla prowadzenia bieżącej działalności firmy. $\mathrm{Na}$ potrzeby narzędzi marketingowych stworzył cztery ścieżki mierników, które zawierają różne perspektywy działalności i tak np. perspektywa klienta dostarcza takich informacji, jak świadomość marki, preferencje zakupowe, deklarację i faktyczny zamiar ponownego zakupu oraz stopień różnicy wynikający z obu czynników. Sprawdzane jest postrzeganie wartości firmy przez klienta i elementów przewagi konkurencyjnej względem firm produkujących substytucyjne produkty. Druga perspektywa to jednostkowa sprzedaż produktów i sposób ich dystrybucji; optymalizacja produktowa i dystrybucyjna. Trzecią perspektywę tworzą mierniki odnoszące się do finansów. Znajdziemy tu takie wskaźniki, jak ROE i ROI oraz zysk netto. Wreszcie ostatnia ścieżka to perspektywa marki, która dostarcza informacji o wartości marki przedsiębiorstwa i jego reputacji ${ }^{13}$.

W opracowaniu Ph. Kotlera ujęte są ponadto takie mierniki, jak:

1. Szczególowe mierniki operacyjne: liczba punktów detalicznych, udział w sklepach prowadzących sprzedaż, dystrybucja ważona, zyski w kanałach dystrybucji, przeciętne (wartościowo) zapasy, cena pokrycia sprzedaży zapasami w dniach, częstotliwość braku towaru, udział na półkach, przeciętna sprzedaż na detaliczny punkt sprzedaży ${ }^{14}$.

\footnotetext{
$12 \mathrm{Ph}$. Kotler, K.L. Keller, op. cit., s. 129.

${ }_{13}$ P. Lapoint, Marketing by the Dashboard Light, Association of National Advertisers 2006, www.marketingNPJ.com.

${ }_{14} \mathrm{Ph}$. Kotler, K.L. Keller, op. cit., s. 692.
} 
Wskaźniki z tej grupy mają za zadanie zobrazować sytuacje umożliwiające klientowi dokonanie zakupu, np. brak towaru, częstotliwość i wielkość dostaw, liczba punktów detalicznych. Przedsiębiorstwo musi zadbać w każdy możliwy sposób o to, aby klient wybrał właśnie jego produkt i miał jak najłatwiejszą drogę zakupu.

2. Mierniki dotyczące komunikacji obejmują: spontaniczną świadomość marki, świadomość marki top of mind, wspomaganą świadomość marki, spontaniczną świadomość reklamy, wspomaganą świadomość reklamy, efektywny zasięg, efektywną częstotliwość, punkt ratingowy brutto (GPR), stopę reakcji ${ }^{15}$.

Oczywiste jest, że wśród tysięcy substytucyjnych produktów należy wyróżnić swój w taki sposób, aby klient znał jego zalety i właściwości i wracał w kolejnych zakupach po ten produkt lub po jego modyfikacje. Wspomaganie świadomości marki i kreowanie jej wizerunku odgrywa tu znaczącą rolę we wsparciu sprzedaży. W przypadku marki ATLAS sp. z o.o. bardzo trudne było wypromowanie produktu, który jest zakrywany eleganckimi płytkami, a sama jego struktura i wygląd nie są atrakcyjne. Marka ATLAS Sp. z o.o. postawiła na wizerunek przywiązania do kraju, narodowości, dumy z bycia Polakami. Taka postawa kreowana i podkreślana na każdym kroku - sponsoring polskich sportowców, fundacja dobroczynności itp. dała jej pozycję najlepiej rozpoznawalnej polskiej marki.

Szacowanie wskaźników powinno odbywać się systematycznie wewnątrz wszystkich elementów tabeli, a tworzenie jej ma na celu wgląd menedżerów najwyższego szczebla w skuteczność działań ich przedsiębiorstwa, rozliczenie odpowiedzialności za uzyskiwane wyniki stosownie do obciążeń, jakie posiadają poszczególne wydziały, ale przede wszystkim po to, aby organizacja skutecznie mogła realizować swoje zadania i powiększać swoją wartość.

Regularność zestawień wskaźników ma pozwolić na obserwację skuteczności działań departamentów marketingu, ale i relacji przedsiębiorstwa z klientami.

Wzrost roli marketingu jest tak olbrzymi, że przedsiębiorstwa, które nie przeorganizują swojego sposobu postrzegania tej dziedziny i korzyści, jakie tracą z powodu jej niewłaściwego wykorzystania, w niedługim czasie zostaną wyparte z rynku. Dawniej marketing był postrzegany jako dziedzina związana z reklamą i promocjami. Obecnie takie spojrzenie jest niedopuszczalne. Umiejętność znalezienia wspólnych odniesień pomiędzy działami finansowymi i marketingowymi wspomaga szybki rozwój przedsiębiorstwa, kreowanie nowych instrumentów finansowych, a także promocje związane z ofertami finansowymi są silnie ze sobą skorelowane i warto znać ich pozytywne i negatywne skutki mogące mieć wpływ na działanie przedsiębiorstwa.

${ }^{15}$ Ibidem. 
Największym błędem współczesnych przedsiębiorstw jest wyciąganie niewłaściwych wniosków z badań marketingowych przez nie prowadzonych, niedocenianie potencjału z nich płynącego. Firmy powinny zwracać szczególną uwagę na czas interpretacji badania od momentu przeprowadzenia go i poprawność wykonania takiej interpretacji. Jak wiadomo nie wszystkie wyniki można porównywać, należy dokładnie ocenić próbę podlegającą badaniu, ich walory kulturowe i znaczenie czy jednostki miary. Istotne jest, aby przedsiębiorstwa upewniały swoich klientów co do konieczności wymiany poglądów na temat produktów zarówno tych pozytywnych, jak i negatywnych, ponieważ przedsiębiorstwo poznaje swoje mocne i słabe strony oczami klienta, a klient ma poczucie „opieki” przedsiębiorstwa i zapewnienia mu największej wygody i korzyści z wybierania danego produkty spośród innych konkurencyjnych.

Najlepszym sposobem, dzięki któremu nie zostanie pominięty żaden z czynników, jest podejście zewnętrzne i wewnętrzne. To pierwsze opiera się na analizie wskaźników interpretujących zjawiska zachodzące na zewnątrz organizacji, jej wpływ na otoczenie bliskie - udział w rynku, wartość przedsiębiorstwa, liczba skarg i stopień zadowolenia klienta z obsługi i produktów, sposób dystrybucji i jakość przeprowadzenia transportu, jakość produktów, liczba klientów łącznie z grupą lojalnych i nowych nabywców. Mgliste pojęcie o sytuacji przedsiębiorstwa rozjaśni analiza wskaźników dotyczących wnętrza organizacji: świadomości i skuteczności realizacji zadań strategicznych przedsiębiorstwa, wielkość generowanego zysku z każdej jednostki majątku przedsiębiorstwa, wielkość zwrotu z inwestycji, wszelkie informacje o kapitale intelektualnym pracowników, chęć wdrażania nowych rozwiązań czy satysfakcja z pracy ${ }^{16}$.

Jednak rozumiejąc istotę doboru wskaźników omówioną w pierwszym podejściu widzimy kontrast w obu podejściach, kształtujący się na obszarze zgodności realizacji zadań strategicznych. Same wskaźniki nie dadzą odpowiedzi odnośnie do skuteczności zarządzania i realizacji strategii, jeżeli nie zostaną dobrane tak jak wskazuje na to pierwsze podejście, tzn. adekwatnie do sytuacji przedsiębiorstwa. Niewielką wiedzę wniesie fakt posiadania tysiąca klientów bez informacji o tempie przyrostu nowych nabywców.

Zgodnie ze znanym angielskim powiedzeniem garbage in garbage out system informacji odda nam tylko taką jakość danych jaką dostanie ${ }^{17}$. Samo wdrożenie dashbordu nie jest rozwiązaniem wszelkich problemów. Głównym pytaniem pozostaje to, jakie informacje i dane potrzebne są firmie do mierzenia tego, co

${ }^{16}$ T. Ambler, What Does Marketing Success Look Like?, „Marketing Management” 2001, Spring, s. 13-18.

${ }_{17}$ Z. Telakowska, Sejsmograf biznesu, czyli wiedza, http://www.nf.pl [dostęp: 06.08.2009]. 
jest niezbędne do osiągnięcia jej celów. Ważne jest więc, aby informatycy znający parametry techniczne systemu dostali szczegółowe definicje wskaźników i odpowiednio skonfigurowali system na potrzeby analityczne biznesu. Należy także wyselekcjonować te dane, które są newralgiczne dla firmy i dla jej zarządu.

Analizy zewnętrzna i wewnętrzna łączą się w procesie formułowania i wdrażania strategii. Jeśli zauważymy także, że z poziomu strategicznego - koncepcyjnego płyną cele, które mają być osiągnięte przez poziom operacyjny, to właśnie z tego poziomu wrócą wyniki i obserwacje z rynku, które pozwalają ocenić realizację zadań i wprowadzić ewentualne korekty działań. Ten proces koncepcyjno-operacyjny powinien być wspomagany przez swój dashboard, czyli narzędzie zapewniające zbieranie ważnych, kluczowych dla firmy informacji, poddawanie ich właściwym analizom, przekazywanie rzetelnych wyników właściwym osobom i potrzebnych im danych we właściwym czasie. Nie jest możliwa budowa właściwej strategii i dalsze jej wdrażanie bez właściwego i efektywnego wspomagania tak informacją, jak i jej analizą otrzymywaną dzięki zastosowaniu dashboardu. Informacja uzyskiwana dzięki kokpitowi, jak i oferowane oprogramowanie jest dla firmy zasobem strategicznym. Pozwala umacniać i rozwijać wiedzę w firmie. Jednak management musi chcieć korzystać z informacji i analiz przy podejmowaniu decyzji.

\section{Zakończenie}

Podsumowując zawarte $\mathrm{w}$ niniejszym artykule rozważania należy zwrócić szczególną uwagę na nowoczesną strukturę marketingu przejawiającą się na wszystkich szczeblach organizacji, następnie na determinanty, jakimi kierują się decydenci przy kreacji przedsiębiorstwa. Ponadto na konieczność stosowania wskaźników przy budowie strategii (główne cele firmy i strategie działania) oraz dobór wskaźników w procesie monitorowania strategii i przedstawiania ich zarządom przedsiębiorstw, konieczność aktualizacji wskaźników. Stąd też w artykule przedstawione zostały ujęcia dwu metod doboru wskaźników marketingowych: tablicy wskaźników oraz tablicy przyrządów marketingowych. Metody te pozwalają na zbieranie jak najdokładniejszych informacji i wskaźników marketingowych i dobieranie ich tak, aby dawały przejrzysty obraz sytuacji ekonomicznej firmy i jednocześnie obraz realizacji jej strategii.

Analiza, monitoring i kontrola działań przedsiębiorstwa mogą być przeprowadzone na wiele sposobów i wiele ich elementów będzie ze sobą zarówno zbieżnych, jak i dających zupełnie inne rezultaty. Ważne jest, aby analitycy wiedzieli 
co chcą zmierzyć, w jakim celu pozyskują dane i co należy z nimi zrobić, aby osiągnąć założone cele.

Metoda tablicy wskaźników marketingowych, zaproponowana w pierwszym podejściu, musi zawierać wskaźniki dające spójną informację, w wielu przypadkach trudno przeprowadzić skuteczną analizę z powodu braku danych lub długiego czasu oczekiwania na zwrotne informacje. Lepiej jednak przeciągnąć czas wykonania analizy niż zbadać niepotrzebnie sektory działalności, zmarnować czas i pieniądze, aby wykreować zamazany lub, co gorsze, błędny obraz działalności firmy.

W przypadku sposobu ukazującego ścieżki mierników, uważać należy, aby obejmowały one elementy istotne dla firmy, warto też czasem zastanowić się nad modyfikacją narzędzia do własnych celów. W efekcie finalnym przecież chodzi o utrzymanie tempa rozwoju przedsiębiorstwa, a nawet wzrostu i ciągłego podnoszenia poziomu konkurencyjności. Jak widać, każde narzędzie, które będzie służyło do analizy działalności firmy ma swoje wady i zalety, ważne jest wyciągnięcie z niego tego, co dla przedsiębiorstwa jest najlepsze. Zawsze w firmie najważniejsi są pracownicy, bo to oni tworzą, zarządzają i pracują w jej obrębie, i to od ich pracy zależą wyniki firmy.

\section{Bibliografia}

Ambler T., What Does Marketing Success Look Like?, „Marketing Management” 2001, Spring

Court D.J., Quelch J.A., Crawford B., McGovern G.J., Zarzad bliżej klientów, „Harvard Business Review Polska” 2008, nr 70

Golik-Górecka G., Zwiększenie efektywności marketingu podstawa sukcesów przedsiębiorstwa - ujęcie najlepszych praktyk - ATLAS Sp. z o.o., [w:]

A. Kaleta, K. Moszkowicz, Zarzadzanie strategiczne $w$ praktyce $i$ teorii, Wyd. Uniwersytetu Ekonomicznego we Wrocławiu, Wrocław 2012

Golik-Górecka G., Perspektywa marketingowo-finansowa a narzędzia decyzyjne zarządu przedsiębiorstw, „Handel Wewnętrzny” 2011, nr 2

Johnson G., Scholes K., Whittington R., Podstawy strategii, PWE, Warszawa 2010

Kąkol W., Strategia a wartość przedsiębiorstwa, „Prace Naukowe UE we Wrocławiu" 2009, $\mathrm{nr} 48$

Kotler Ph., Marketing. Analiza, planowanie, wdrażanie i kontrola, Rebis, Warszawa 2010

Kotler Ph., Keller K.L., Marketing, Pearson Education, Poznań 2012 
Lapoint P., Marketing by the Dashboard Light, Association of National Advertisers 2006, www.marketingNPJ.com

Milewski R., Kwiatkowski E., Podstawy ekonomii, Wyd. Nauk. PWN, Warszawa 2005

Telakowska Z., Sejsmograf biznesu, czyli wiedza za... http://www.nf.pl

http://www.atlas.com.pl/o-nas/cele-strategiczne-firmy.html 